\title{
Macacos também choram, ou esboço para um conceito ameríndio de espécie
}

\author{
[ Weeping monkeys, or outline of an Amerindian concept of species
}

\section{Uirá Garcia ${ }^{\mathrm{I}}$}

\begin{abstract}
Este texto é uma versão modificada de comunicação proferida na mesa-redonda "Vida multiespécie” na VI Reunião de Antropologia da Ciência e da Tecnologia - ReACT (maio de 2017 na USP), na qual retomei (como "autoplágio") argumentos de publicações anteriores. Trata-se de esboços inéditos acerca de noções guajá (povo indígena com que venho trabalhando há II anos) como caça, criação, espécie, vida multiespécie, dentre outras. Agradeço a Joana Cabral de Oliveira, Stelio Marras e Renzo Taddei pelo generoso convite e pela publicação deste artigo. Agradeço à Fapesp pelo auxílio a esta pesquisa.
\end{abstract}

\begin{abstract}
RESUMO - Este artigo discute parte das práticas de conhecimento relativas aos animais e à caça de macacos entre os Guajá, considerando o processo de destruição de seus territórios. O artigo explicita conexões feitas e refeitas continuamente, em um regime que relaciona humanos e animais, sem, no entanto, recorrer à ideia de que caça e criação seriam formas complementares de relação com os animais. Sugiro que as maneiras como humanos e bugios vivem juntos talvez encontre aqui outra forma de pensar a própria ideia de “espécie”. O desafio a mais do artigo está em refletir, a partir dessa "noção indígena de espécie", como poderíamos pensar outros fenômenos, por exemplo, o surto de febre amarela experimentado no Sudeste brasileiro no ano de 20I7. PALAVRASCHAVE - Macacos; caça; espécie; febre amarela; Guajá. • ABSTRACT · This article explores part
\end{abstract}

of the Guajá knowledge practices related to animals and to the hunting of howler monkeys, considering the ongoing process of their territory destruction. The article puts forward the connections, constantly done and undone, in a regime that relates humans and animals in many ways. There is no intention, however, to appeal to the idea that hunting and nurturing would be complementary ways of relating to animals. The challenge of understanding revealed by the ways that humans and monkeys live together, may point to an alternative form to think the very concept of "species". The extra challenge of this article is to explore, from this "notion of species", how could we think other phenomena, such as, for instance, the yellow fever burst experienced in the southeast Brazil in 20I7. KEYWORDS . Monkeys; hunting; species; yellow fever; Guajá.

Recebido em 5 de novembro de 2017

Aprovado em 28 de fevereiro de 2018

GARCIA, Uirá. Macacos também choram, ou esboço para um conceito ameríndio de espécie. Revista do Instituto de Estudos Brasileiros, Brasil, n. 69, p. I79-204, abr. 2018.

DOI: http://dx.doi.org/Io.II606/issn.23I6-90IX.voi69pI79-204

I Universidade Federal de São Paulo (Unifesp, São Paulo, SP, Brasil). 


\section{MACACOS TAMBÉM CHORAM, OU ESBOÇO PARA UM CONCEITO AMERÍNDIO DE ESPÉCIE}

Este artigo discute uma ideia há tempos elaborada por diversas etnografias, tanto sobre coletivos indígenas sul-americanos como sobre outros povos subjugados do mundo: o fato de que "Histórias apenas-humanas não servirão a ninguém”. Se, de um lado, enquanto etnógrafos, sabemos que nossos amigos e interlocutores em campo nunca deixaram de "viver com"3 e levar a sério, não só os animais, mas uma multiplicidade de fenômenos que nós reduziríamos à natureza, de outro, uma espécie de surdez etnocêntrica, "a surdez dos brancos", como escrevem Davi Kopenawa e Bruce Albert ${ }^{4}$, nos impede de conceber o "social" como uma comunidade mais ampla que abarcaria outras perspectivas do que é ser "humano" e ser "animal”. Essa crítica à antropologia em particular pode ser estendida às ciências sociais no geral, como vêm mostrando autores que se filiam ao que agora é chamado "etnografias multiespécies"6. A noção de que o estudo correto do homem é a humanidade, como argumenta Donna

2 VAN DOOREN, Thom; KIRKSEY, Eben; MÜNSTER, Ursula. Estudos multiespécies: cultivando artes de atentividade. ClimaCom, ano 3, n. 6, Dossiê Incertezas, 20I6, p. 39-65. p. 4I. Disponível em: <https://goo.gl/ uU27dR>. Acesso em: I5 de set. 2017 .

3 DESPRET, Viniciane. The body we care for: figures of anthropo-zoo-genesis. Body and Society, v. Io, n. 2/3, 2004, p. III-I34. http://dx.doi.org/Io.II77/I357034X04042938. As traduções das citações são minhas.

4 KOPENAWA, Davi; ALBERT, Bruce. A queda do céu: palavras de um xamã Yanomami. São Paulo: Companhia das Letras, 20I5, p. 47.

5 LATOUR, Bruno; STRUM, Shirley. The meanings of social: from baboons to humans. Information sur les sciences sociales/Social Science Information, 26, I987, p. 783-802; VIVEIROS DE CASTRO, Eduardo. O nativo relativo. Mana, v. 8, n. I, 2002, p. II3-I48. http://dx.doi.org/Io.I590/s0I04-93I32002000I00005.

6 KIRKSEY, S. Eben; HELMREICH, Stefan. The emergence of multispecies ethnography. Cultural Anthropology, v. 25, n. 4, 20Io. http://dx.doi.org/Io.IIII/j.I548-I360.20I0.oIo69.x; OGDEN, Laura A.; HALL, Billy; TANITA, Kimiko. Animals, plants, people, and things: a review of multispecies ethnography. Environment and Society: advances in research, 4, n. I, 20I3, p. 5-24. http://dx.doi.org/Io.3I67/ares.20I3.040IO2; VAN DOOREN, Thom; KIRKSEY, Eben; MÜNSTER, Ursula, op. cit. 
Haraway, é risível entre a maioria dos biólogos, "cuja curiosidade gira, na verdade, em torno de outras criaturas"?. Em outras palavras, e como sabemos desde, pelo menos, Bruno Latour", a teoria social nunca levou a sério a multiplicidade de "não humanos" - apesar de nossas vidas serem atravessadas por isso. Nossas ciências sociais parecem resistir aos trabalhos que há tempos nos apresentam vidas compartilhadas entre humanos, animais e plantas, sobretudo àqueles interessados em caça, pastoralismo, cultivo, paisagem, xamanismo, cujos fenômenos colocam em relação humanos e não humanos, a serem pensados em conjunto. Esse é um "ponto cego"y na nossa teoria social, ou um deles. Apesar de a história humana ser a história dos humanos em relação a tantos não humanos ${ }^{\mathrm{IO}}$, tais seres nunca foram tratados com seriedade, como parte de nossos mundos sociais. Nunca formaram conosco um coletivo.

O debate proposto na mesa na ReACT ${ }^{\mathrm{II}}$, de onde esse artigo é oriundo, girava em torno da ideia de "vida multiespécie", cujo principal postulado está justamente em retirar a centralidade do humano de nossa teoria social. Como sabemos, essa ideia não é exatamente "nova" ${ }^{2}$, no entanto, ela inaugurou um paradigma que modificou de forma definitiva o que chamamos de fazer antropológico. Não se trata apenas de algumas etnografias, de alguns poucos antropólogos, interessadas em animais e plantas, mas sim de entender que há um contínuo entre humanos e não humanos no que se refere às formas de ocupar o mundo. Um "becomig with", nas palavras de Donna Haraway ${ }^{\mathrm{I}}$, que designa devires e compartilhamentos em um mundo de "gentes", onde os humanos, tal como os concebemos, não podem existir ${ }^{\mathrm{I}}$. Talvez já tenha passado da hora de aceitarmos que a história da humanidade é composta por camadas heterogêneas de biologia, de naturezasculturas, transferências de DNA, endossimbioses, simbiogêneses e outras maravilhas que moldaram nosso jogo de sobrevivência ${ }^{\mathrm{I}}$.

A ideia de que o estudo correto do humano é a humanidade, portanto, foi posta em xeque por trabalhos não tão recentes assim ${ }^{16}$, além de ser o grande tema da etnologia

7 HARAWAY, Donna. When species meet. Minneapolis: University of Minnesota Press, 2008, p. 70; HARAWAY, Donna. HARAWAY, Donna. A partilha do sofrimento: relações instrumentais entre animais de laboratório e sua gente. Horizontes Antropológicos, v. I7, n. 35, 20II, p. 27-64. http://dx.doi.org/Io.I590/s0I04-7I8320II000I00002.

8 LATOUR, Bruno. Jamais fomos modernos: ensaios de antropologia simétrica. São Paulo: Editora 34, I994.

9 INGOLD, Tim. Anthropology beyond humanity. Suomen Anthropologi, v. 38, n. 3, 2013, p. 5-23. p. I6.

Io LATOUR, Bruno. Políticas da natureza. Bauru: Edusc, 2004.

II A mesa organizada por Joana Cabral foi composta por Felipe Süssekind, por Igor Scaramuzzi e por mim, tendo como debatedor Guilherme Sá.

I2 INGOLD, Tim, 20I3, op. cit, p. I9.

I3 HARAWAY, Donna, 2008, op. cit.

I4 DANOWSKI, Déborah. VIVEIROS DE CASTRO, Eduardo. Há mundo por vir? Ensaio sobre os medos e os fins. Florianópolis: Cultura e Barbárie, 20I4, p. I45-I46.

I5 HARAWAY, Donna, 2008, op. cit., p. I6.

I6 HALLOWELL, Irving. Ojibwa ontology, behavior and world view. In: DIAMOND, Stanley. Culture in history: essays in honor of Paul Radin. New York: Columbia University Press, I960, p. I9-52; INGOLD, T. On reindeer and men. Man (New Series), v. 9, n. 4, I974, p. 523-538. http://dx.doi.org/I0.2307/280II22. 
americanista nas últimas décadas, como vemos, por exemplo, nas preocupações ecológicas de Philippe Descola. Mas me refiro antes de tudo ao tropo perspectivista, dos trabalhos de Eduardo Viveiros de Castro e Tânia Stolze Lima, com a presença de múltiplos pontos de vista na caça e na vida, onde a diversidade ecológica vai além, em uma verdadeira "filosofia multiespécie". Paralelamente, um conjunto de autores, através da discussão humano-animal, em antropologia e áreas correlatas ${ }^{17}$, vem contribuindo para o desenvolvimento de uma antropologia (e filosofia) preocupada com os nossos "emaranhamentos" lembrando-nos que "jamais fomos humanos" de domesticação onde não apenas controlamos (ou pensamos controlar) as espécies, mas onde o oposto é também verdadeiro ${ }^{20}$.

$\mathrm{Na}$ etnologia americanista (mas não apenas), a questão se complexifica, pois etnograficamente pensamos com nossos colegas e amigos indígenas os problemas conceituais subjacentes a ideias como natureza, animal e espécie, e nesse movimento acabamos por encontrar conceitos diferentes de natureza, animal e espécie ${ }^{2 \mathrm{I}}$. A minha própria experiência nesse "campo" ${ }^{22}$ se dá a partir desse lugar específico, interessando-me por objetos como "caça”, "parentesco", "xamanismo", "contato", dentre outros ${ }^{23}$. A meu ver, o que vincula política e epistemologicamente parte da produção etnológica sul-americana atual aos chamados "estudos multiespécies" é o esforço que ambos empreendem na compreensão conceitual de variadas formas de vida que se correlacionam, sem recorrerem a simbolismos ou sobrecodificações que retirariam, justamente, a potência de outras ideias e outros mundos. Penso, por

I7 Apenas para citar nomes (e não obras) de pessoas que vêm trabalhando com a interação direta entre vidas humanas e não humanas nas ciências sociais: Anna Tsing, Agustín Fuentes, Eduardo Kohn, Natasha Fijn, Stefan Helmreich, Vinciane Despret, Donna Haraway, Thom Van Dooren, Dominique Lestel. No Brasil, refiro-me a trabalhos como os de Felipe Süssekind, Felipe Vander Velden, Thiago Mota Filho, Gabriel Barbosa, Carlos Sautchuk, Joana Cabral de Oliveira, Igor Scaramuzzi, Guilherme Sá, Ana Gabriela Morim, Marilena Altenfelder Campos, Jean Segata, Pedro Castello Branco Silveira, Fabiano Bachellay, dentre outros que me fogem à memória.

I8 RAFFLES, Hugh, 2002 apud KOHN, Eduardo. Como os cães sonham: naturezas amazônicas e as políticas do engajamento transespécies. Ponto Urbe I9, 20I6, p. I-35. http://dx.doi.org/I0.4000/pontourbe.3326.

I9 HARAWAY, Donna, 2008, op. cit.

20 TSING, Anna. Margens indomáveis: cogumelos como espécies companheiras. ILHA, v. I7, n. I, 20I5, p. I77-20. http://dx.doi.org/I0.5007/2I75-8034.20I5VI7nIpI77.

2I BARRETO, João Paulo. Wai-Mahsã: peixes e humanos - um ensaio de antropologia indígena. Dissertação (Mestrado em Antropologia Social). Programa de Pós-Graduação em Antropologia Social, Universidade Federal do Amazona, 20I3, p. 85; VIVEIROS DE CASTRO, Eduardo, 2002, p. I34-I36.

22 Van Dooren, Kirksey e Münster lembram que “estudos multiespécies” (ideia que também vem encontrando críticas: INGOLD, Tim, 20I3, op. cit.) é um “termo guarda-chuva”, que nomeia um conjunto heterogêneo de pesquisas. VAN DOOREN, Thom; KIRKSEY, Eben; MÜNSTER, Ursula, op. cit., p. 43.

23 Há II anos venho trabalhando com os Guajá, povo indígena falante de uma variante do tupi-guarani, que estão em uma das regiões de floresta tropical mais desmatadas do mundo, o leste amazônico, no estado do Maranhão, próximo à divisa com o estado do Pará. 
exemplo, em minhas estadias na floresta maranhense, quando um arco-íris aparece no céu e um amigo Guajá me chama para dizer "olhe, os espíritos estão levando água para o céu”; ou quando, depois da chuva, alguém aponta para o barranco do rio e diz: "você está ouvindo? As minhocas estão cantando". Dentre outras situações que no trabalho de campo nos retiram de nossa zona de entendimento dos fenômenos da "natureza", somos obrigados a repensar os conceitos e ideias tais como nós os concebemos, e não tratá-los como "imagens", "metáforas", "símbolos" etc. Levar as observações de nossos interlocutores a sério é, além de não as tomarmos como alegóricas, partir do pressuposto de que, antes de tudo, "a natureza humana é uma relação entre (diferentes) espécies” 4 - e também, é claro, levar em consideração o fato de que nossos amigos não seriam tão surdos (e cegos) a esses emaranhados quanto nós.

Não quero sugerir, no entanto, que os povos indígenas são a própria natureza, seus grandes protetores e conhecedores. Esse é um fardo que pelo menos os Guajá não querem carregar. O que trago aqui são outras formas de conexões, cujos resultados ecológicos na paisagem são, de fato, muito melhores do que os nossos. Os Guajá, bem como outros povos, estão interessados em conexões que nós sequer concebemos possíveis (a não ser alguns cientistas preocupados com modelos de interação humano-animal e homem-ambiente). E mesmo que nossa imaginação consiga alcançar formações geológicas, rios e até geleiras, pensando-os como modos de vida distintos ${ }^{25}$, nossas interações com essas vidas são bastante desatentas. Alternativa a essa leitura, está a atenção que meus interlocutores têm com fenômenos como, por exemplo, o "vento", pensado como uma espécie de "pessoa", Wutu Jara ("gente-vento", ou mesmo "dono do vento"). O maior prazer dessa gente-vento é fazer barulho nas folhas das árvores e "quebrar os galhos", pois assim eles gostam. Eles gostam do barulho. Em casos de muita ventania, é ainda possível espantar essa gente-vento. Deve-se cantar a canção de Takwaripĩnĩ' $̂ a, a$ a "gente-taquara", como uma maneira de espantar ventanias ou mesmo tormentas. Podemos pensar que essa "gente-taquara" consegue controlar a "gente-vento", e ambos esses modos de vida vivem em aldeias distantes e andam (caçam) na mesma mata que os Guajá. Em outras palavras, as pessoas com quem trabalho conseguem conectar suas existências não só ao vento, as taquaras, mas também aos macacos, jabotis, cigarras, mortos, brancos, dentre tantas outras potências, de uma maneira complexa e criativa. "Complexidade é o nome do nosso jogo" ${ }^{26}$. Um jogo que revela, por exemplo, um elaborado conhecimento sobre os animais, seja numa espécie de "ciência do concreto" com fins específicos (para a caça, ou a criação de filhotes), ou mesmo para o exercício de uma "paixão"27, como é o caso do "canto" do macaco capelão, como veremos a seguir.

O complexo regime que conecta humanos e capelães (Alouatta belzebul) impõe um desafio a mais para a empreitada etnográfica, em diálogo com a maneira como diversos autores vêm pensando através de ideias, diferentes mas não dissonantes,

24 TSING, Anna, 20I5, op. cit.

25 VAN DOOREN, Thom; KIRKSEY, Eben; MÜNSTER, Ursula, op. cit., p. 42.

26 HARAWAY, Donna, 2008, op. cit., p. I6

27 TSING, Anna. Arts of inclusion, or, how to love a mushroom. Australian Humanities Review 50, 20II, p. 5-22. p. I9. 
como "antropologia da vida" 28 , "antropologia-para-além-do-humano" 29 , "naturezasculturas"30, dentre outras. Por isso, e não apenas no meu caso, a etnografia não poderá deixar de se interessar pelas "mutualidades", não apenas humanas - do parentesco, por exemplo ${ }^{3 \mathrm{I}}$ - mas outras que mobilizam uma economia de afetos transespecíficos, centrais no pensamento ameríndio. Este artigo pretende, assim, explicitar conexões pouco óbvias entre os Guajá e os capelães. Essa mirada radical na vida de macacos talvez faça parte daquela reeducação do etnógrafo feita "por aqueles que aceitaram sua presença, para servir de intérprete a serviço de sua causa”32. Nessa reeducação, nesse "engajamento mútuo"33, meu e dos Guajá, uma das coisas que transbordaram na minha pesquisa foi essa espécie de "imersão apaixonada” na vida de alguns animais ${ }^{34}$.

Isso passa, por exemplo, pelo quanto os Guajá me ensinaram sobre a vida partir dos macacos. Não qualquer espécie, mas justamente o wari (na língua Guajá), conhecido em boa parte da Amazônia como "capelão". Esse é o nome dado a macacos do gênero Alouatta, também conhecidos como "bugios", cuja espécie em questão é o Alouatta belzebul ${ }^{35}$. Dentre as seis espécies de bugios encontradas nas florestas tropicais centro-sul americanas ${ }^{36}$, essa é chamada de "guariba-de-mãos-ruivas", dentre outros nomes ${ }^{37}$. Esse macaco "canta", e é exatamente esse cantar que mais interessa aos Guajá, para além de sua saborosa carne. A cantoria dos macacos costuma ocorrer no final da tarde, na copa de alguma árvore, onde o bando de entre dois e oito indivíduos (uma família) costuma se reunir. O que a nossa primatologia chamaria de vociferação (que nada mais é do que a "produção de gritos"), a primatologia guajá pensa como uma vocalização (que é a produção de cantos) ${ }^{38}$. Recorrendo à minha memória, não consigo pensar em nenhum outro primata que conceberíamos como capaz de "cantar", a não

28 KOHN, Eduardo, 20I6, op. cit.

29 Idem. How forests think: toward an anthropology beyond the human. Berkeley: University of California Press, 20I3; INGOLD, Tim, 20I3, op. cit.

30 HARAWAY, Donna, 2008, op. cit.

3I SAHLINS, Marshall. What kinship is (part one). JRAI - Journal of the Royal Anthropological Institute, v. I7, n. I, 20II, p. 2-I9. http://dx.doi.org/I0.III/j.I467-9655.20I0.oI666.x; SAHLINS, Marshall. What kinship is (part two). JRAI - Journal of the Royal Anthropological Institute, v. I7, n. 2, 20II, p. 227-242, 20II. http://dx.doi. org/Io.IIII/j.I467-9655.20II.0I677.x.

32 KOPENAWA, Davi; ALBERT, Bruce, op. cit., p. 520-523.

33 Ibidem.

34 TSING, Anna, 20II, op. cit, p. I9.

35 CORMIER, Loretta A. Kinship with monkeys: the Guajá foragers of eastern Amazonia. New York: Columbia University Press, 2003.

36 EMMONS, Louise H. Neotropical rainforest mammals: a field guide. Chicago: University of Chicago Press, I999.

37 Também conhecido como: guariba-de-mãos-ruivas, guariba-de-mãos-vermelhas, guariba-preta ou bugio-de-mãos-ruivas. ALOUATTA belzebul. Wikipédia. Disponível em: 〈goo.gl/hNPDmt〉. Acesso em: I5 set. 20I7. Para detalhes sobre a espécie, ver: Emmons, I999, op. cit., p. I37-I38.

38 Em inglês, os primatas do gênero Alouatta são conhecidos como howler monkeys, "macacos uivadores". O próprio nome em português, “capelão”, denota uma sonoridade monocórdica, algo como uma reza. 
ser nós mesmos. Então, se no universo guajá macacos podem cantar, imaginem o que mais eles não são capazes de fazer. Falo de coisas muito práticas, como amolar facas, por exemplo. Os macacos-pregos das aldeias onde trabalho são capazes de fazê-lo, como já testemunhei. É claro que ninguém quer ver macacos-pregos amolando facas, sobretudo porque, no círculo familiar, esses animais disputam a atenção das mulheres, e muitas vezes atacam as crianças com inesperadas mordidas. Imaginem então o que eles não fariam com uma faca ${ }^{39}$.

Os macacos nos levam para esse outro mundo e modo de vida compartilhado, como quero apresentar aqui. Meu grande interesse por esses animais sempre se deveu ao seu estatuto de caça. Se perguntássemos o que seria a caça, para as pessoas nas aldeias, uma das respostas imediatas seria que "caça é comida". Pode parecer estranho, mas o fato de macacos serem animais caçáveis (e comíveis) é motivo para um interesse e admiração genuína para com esses animais, por parte de meus interlocutores e, consequentemente, para mim. Por isso, antes de prosseguir, gostaria de descrever, de forma um tanto sucinta, como os macacos aparecem enquanto caça.

\section{ESPANTAR O CAPELÃo}

Uma das vezes em que acompanhei uma dessas caçadas, saímos em um grupo de cinco ou seis homens, três ou quatro mulheres e algumas crianças. Takya, um homem velho, havia encontrado indícios (pelos, fezes e urina, encontrados no chão e na vegetação) de um grupo de guaribas em um ponto distante da mata. Deixamos a aldeia por volta de $6 \mathrm{~h} 30$ e andamos por cerca de duas horas. Debaixo da árvore, não se percebia qualquer sinal da presença de macacos. Enquanto descansávamos e os homens preparavam suas flechas e espingardas para iniciarem a caçada, foram chegando outras pessoas que saíram da aldeia depois mas sabiam exatamente em que local estaríamos. Enquanto mordia e torcia suas flechas, a fim de certificar-se se eram os projéteis adequados para subirem com ele na árvore, Takya cantarolava (bem baixinho, quase gemendo) o tema musical de Juxa'a (gente espinho-da

39 Diversos autores vêm trabalhando com interações diversas entre humanos e primatas sob o paradigma da etnoprimatologia, em que discussões como esta ganham um interesse especial. Ver: FUENTES, Agustín. Naturalcultural encounters in Bali: monkeys, temples, tourists, and ethnoprimatology. Cultural Anthropology, v. 25, n. 4, 2010, p. 600-624, 2010; FUENTES, Agustín. Ethnoprimatology and the anthropology of the human-primate interface. Annu. Rev. Anthropol, n. 4I, 20I2, p.IOI-II7. Para o caso amazônico, ver os artigos: CORMIER, Loretta. Monkey as food, monkey as child: Guajá symbolic cannibalism. In: FUENTES, Agustín; WOLFE, Linda D. (Org). Primates face to face: conservation implications of human-nonhuman primate interconnections. Cambridge: Cambridge University Press, 2002, p. 63-84; LIZARRALDE, Manuel. Ethnoecology of monkeys among the Barí of Venezuela: perception, use and conservation. In: FUENTES, Agustin; WOLFE, Linda D. (Org). Primates face to face: conservation implications of human-nonhuman primate interconnections. Cambridge: Cambridge University Press, 2002, p. 85-Ioo; e SHEPARD, Glenn. Primates in Matsigenka subsistence and world view. In: FUENTES, Agustin; WOLFE, Linda D. (Org). Primates face to face: conservation implications of human-nonhuman primate interconnections. Cambridge: Cambridge University Press, 2002, p. IOI-I36. 
-palmeira-marajá), um karawara ("espírito celeste") $4^{40}$ caçador de capelães, como se isso fizesse parte de seu processo preparatório (caça e música estão intimamente articulados na vida guajá). A canção insinua, de forma sussurrada, que os capelães serão mortos bem rápido e quem está ali embaixo são grandes caçadores e comedores de guariba, tal como os espíritos celestes Juxa’a. De acordo com meus interlocutores, isso faz com que os animais tremam de medo. Todos conversam alto. As mulheres ficam assobiando um ponto único, repetitivo, e pedem que eu faça o mesmo. Os assobios, chamados opia, são utilizados para que os capelães se assustem com a presença humana. Eles me explicam que é importante que os guaribas saibam que os homens estão ali embaixo, pois assim ficam com medo, pensam que se trata de "madeireiros", ou qualquer outro tipo de sujeito que os ferirá. Aos poucos, cada homem - portando uma espingarda ou um arco e flechas - se espalha em outras grandes árvores situadas estrategicamente em volta da árvore dos animais. Enquanto outros homens sobem silenciosamente nas árvores (ipi wate - "subir para o alto") ao redor, tomando cuidado para que os guaribas não atentem para suas ações, Takya sobe o mais próximo que consegue da copa da árvore onde os animais se escondem.

Uma vez lá em cima, observa, mexe nas folhas e tenta encontrar algum vestígio ou esconderijo do camuflado grupo de bugios. Quando, finalmente, se certifica de que estão ali, inicia uma fala muito específica. No cerco que se inicia, ganha vida um processo comunicativo em que o animal é ameaçado, escorraçado de seu abrigo de folhas. Muitos gritos são dados, principalmente por quem está lá em cima, enquanto quem permanece no solo também ajudará com gritos e assobios. Com palavras soltas e gemidos idênticos ao dos guaribas, incitando o bando a correr dali, Takya grita:

\author{
Corra capelão rrrrrr, ah ah aaah \\ corra capelão \\ rrrrrr, ah ah \\ corra, ah ah \\ corra mesmo para fora daí \\ rrrrrr, ah ah \\ saia realmente correndo \\ corra capelão, rrrrrr, ah ah aaah ${ }^{4 I}$.
}

Trata-se de uma impressionante forma de conexão entre caçadores e presas. E os macacos também começam a roncar seu som característico, a ponto de não sabermos qual é a voz humana e qual é o som do animal. A fala é pontuada por sons idênticos aos dos animais, e proferida até que surta algum efeito: que eles fujam em direção às outras copas de árvores, onde encontrarão a morte pelas mãos de outros caçadores que os estarão esperando. O wari papopo ("espantar o capelão") é uma técnica bastante eficiente e compõe o aparato de caça guajá. Nessa emboscada aérea, os animais devem ser espantados para que, ao fugirem, literalmente se atirem contra os caçadores. Por

40 GARCIA, Uirá. Karawara: a caça e o mundo dos Awá-Guajá. Tese (Doutorado em Antropologia Social).

Faculdade de Filosofia, Letras e Ciências Humanas, Universidade de São Paulo, 2010.

4I Em minha livre tradução. 
isso, tais emboscadas são bem-sucedidas se realizadas nas primeiras horas do dia, quando os animais ainda estão dormindo.

Algo a se destacar nessa relação é o fato de as pessoas, a partir de uma primatologia particular, fazerem uma distinção categórica entre o que é chamado de macaco (por um lado) e capelão (por outro). Se no grupo dos macacos (chamados $k a^{\prime} i$ ) estariam o macaco-prego (Cebus apella), o cuxiú-preto (Chiropotes satanas), o cairara (Cebus kaapori), o macaco-de cheiro (Saimiri sciureus) e mesmo os que não existem em suas terras, como o "barrigudo" e o "macaco-aranha”, nesse grupo de macacos não entraria o capelão (chamado de wari). O principal argumento é que esse animal é mais "sensível" (ou "mole", como dizem). Dentre outras coisas, tem uma dieta mais seletiva, tem mais medo dos humanos, e sabe "cantar bonito".

Ao lado disso, nas aldeias guajá os capelães (bem como outros animais) são tanto caçáveis quanto criáveis. As casas são repletas de animais que podem superar o número de seres humanos em uma residência ${ }^{42}$. São macacos, jacus, quatis, jacamins, corujas, araras, tucanos, cotias, pacas, tartarugas, porcos e até filhotes de jaguares, criados pelas mulheres, crianças e, em alguns casos, por homens. Os filhotes capturados devem ser muito pequenos, pois aqueles um pouco maiores são difíceis de amansar, e ainda poderão alguma hora se vingar da morte de seus pais atacando, principalmente, as crianças. Filhotes de macacos, queixadas, caititus, esquilos quatipurus, cotias, papagaios, quatis e macacos-da-noite são criados na aldeia e quase todos acompanham suas donas em caçadas e incursões pela floresta. Como em outros povos da América do Sul ${ }^{43}$, ao chegar nas aldeias, os animais quase sempre são modificados. Aves têm parte de suas penas retiradas ou aparadas para que não consigam fugir, bem como as pontas seus bicos são cortados com tesouras para que, ao bicarem, não machuquem ninguém. As afiadas garras de quatis são retiradas ou lixadas com lima. Paquinhas e filhotes de cotias têm seus dentes serrados (também com lima) para que as pontas cortantes não firam ninguém. Queixadas e caititus devem ficar bem amarrados, ou presos em currais, para que o corre-corre dos bichos não transforme a aldeia em uma grande bagunça e gritaria; esses animais comem tudo o que encontram pela frente, de lixo a pintinhos. Apenas os macacos parecem não sofrer tantas interferências como cortes e outras injúrias. Com os macacos nada se faz. Quando muito, são presos com cordas finas, por algum tempo, até ficarem mansos. Os que não se acalmam permanecem amarrados até um dia serem soltos de volta na floresta.

Separar caça e criação como atividades complementares, entre homens e mulheres, é algo que os Guajá não fazem. Ao menos de maneira óbvia, como uma divisão de tarefas. Apesar de a floresta ser pensada como um local perigoso para as mulheres - e do fato de os homens no geral se utilizarem de armas para caçar e as mulheres não -, em nenhum momento homens defendem que a caça é uma atividade masculina em oposição a uma outra atividade (como a coleta), que seria feminina.

42 CORMIER, Loretta, 2002, op. cit.

43 VANDER VELDEN, Felipe Ferreira. Inquietas companhias: sobre os animais de criação entre os Karitiana.

São Paulo: Alameda, 20I2, p. II2-II7. 
Evocando aqui a crítica de Marilyn Strathern ${ }^{44}$, o próprio par referente à esfera doméstica, representada pelos animais de criação - filhotes cujo manejo da vida depende das mulheres -, e à esfera selvagem, concebida nos animais de caça, tendo os homens como agentes privilegiados dessa relação, deve ser visto com cautela, uma vez que os animais de criação que acompanham mulheres à mata o fazem não apenas se limitando a uma espécie de adereço em seus corpos (como sugere Cormier ${ }^{45}$ ). Em conexão com suas donas, macacos-pregos e cairara, atentos às caminhadas, podem alertar com assobios e gritos sobre cobras e aranhas venenosas durante o trajeto ${ }^{46}$. Acredito que uma maneira não apenas poética, mas também muito verdadeira, de pensar tal fenômeno seria através da ideia de "espécie companheira", em que ambos, mulheres e macacos, se afetam mutualmente. Macacos que falam, mulheres que entendem, assim é a criação de filhotes.

O mesmo pode ser visto com os cachorros. Desde a introdução desses animais nas atividades de caça, as mulheres passaram a andar com mais "segurança" no mato, menos receosas de serem atacadas por onças, e grupos de mulheres com seus cachorros costumam ser muito eficientes em caçadas. Se a floresta é um local perigoso para as mulheres, como os homens costumavam me dizer, com os cães os riscos são amenizados. Os animais de criação aqui, longe de serem seres exclusivos da aldeia (esfera doméstica) em oposição à pura predação de uma suposta esfera selvagem, são importantes na mata. Como já pontuei alhures, o fato de homens desaconselharem mulheres a entrarem sozinhas na floresta, e de a caça acontecer na mata, não pode ser reduzido à ideia de que a caça seja uma atividade masculina por excelência, embora seja bastante desejável pela "mulherada" (awa wahykera) que os homens cacem para as esposas, e muito do que mulheres mais velhas apreciam ao se casar com homens mais jovens é que eles caçarão para elas. Por outro lado, o fato de animais serem domesticados é o que, de muitas maneiras, colabora para que as mulheres cacem mais, com mais vigor e qualidade, empurrando-as - com mais segurança, pois esse é um ponto importante aqui - ainda mais para a floresta.

Se em um primeiro momento a criação de animais cativos nas aldeias amazônicas, ao menos para os Guajá, pode aparecer como uma versão indígena daquilo que Anna Tsing chama de "prisão perpétua", à qual as nossas espécies domésticas são condenadas quando viram nossos animais de criação.

A domesticação é geralmente compreendida como o controle humano sobre outras espécies. Que tais relações podem também transformar os humanos é algo frequentemente ignorado. Além disso, tende-se a imaginar a domesticação como uma linha divisória: ou você está do lado humano, ou do lado selvagem. [...] Por meio dessas fantasias, as espécies domésticas são condenadas à prisão perpétua e

44 STRATHERN, Marilyn. No nature, no culture: the Hagen Case. In: MACCORMACK, Carol; STRATHERN, Marilyn (Org.). Nature, culture and gender. Cambridge: Cambridge University Press, I980, p. I74-222.

45 CORMIER, Loretta, 2002, op. cit.

46 SANTOS, Rosana de Jesus Diniz. Awa Papejapoha: um estudo sobre educação escolar entre os Awá Guajá/ MA. Monografia (Especialização em Desenvolvimento e Relações Sociais no Campo). Universidade de Brasília, 20I5, p. 65. 
à homogeneização genética, enquanto as espécies selvagens são "preservadas" em bancos de germoplasma enquanto suas paisagens multiespécies são destruídas. Apesar desses esforços extremos, a maioria das espécies dos dois lados da linha, incluindo os humanos, vive em complexas relações de dependência e interdependência. Prestar atenção a essa diversidade pode ser o início da apreciação de um modo interespecífico de ser das espécies ${ }^{47}$.

Por outro, meus amigos problematizam a própria ideia de controle humano sobre essas espécies. De maneira mais direta, o que está em jogo aqui, novamente, é a dicotomia entre selvagem e cultivado/doméstico, entre aldeia e mata ${ }^{48}$, que muitas vezes nos informa a maneira que escrevemos sobre tais fenômenos. Para fazer um contraponto, no caso guajá, as "prisões" não são perpétuas, uma vez que: I) macacos e tantos outros animais, caso não morram jovens, alguma hora irão embora, fugirão de volta para a floresta; e 2) não existe um controle total sobre os corpos desses animais (mesmo muitos desses corpos sofrendo modificações), ou preocupações que procurem dominar suas ações cotidianas. Além disso, a própria dicotomia entre casa e mata, entre doméstico e selvagem, é criticada pelo "modelo" guajá, e essa é uma das condições para a criação de animais. Muitos deles não são criados dentro de casa, mas soltos na periferia da aldeia ou mesmo na capoeira. Os jacamins de criação (Psophia viridis), por exemplo, são espécies que sempre irão dormir empoleiradas no alto das árvores embora tenham donos humanos definidos. Criação aqui não se confunde com domesticação.

\section{ANDAR JUNTO}

Sabendo superficialmente como se dão a caça e a criação de macacos, gostaria de mencionar um outro episódio em particular. Nesse dia caçávamos macacos-pregos (Sapajus apella). Ao fim da caçada, as pessoas que se dispersam no corre-corre costumam se reunir antes de voltarem para casa. Como é esperado nessas horas, cada um traz o resultado de sua perseguição arremessando-a ao chão, quando todos ficam curiosos, comentando a quantidade, o tamanho, o sexo, a dose de gordura e outras coisas. Nesse dia, no emaranhado de animais abatidos sobre o solo, percebi que uma das fêmeas carregava um filhote que fora abatido com ela (lembro aqui que os caçadores só poupam a vida de filhotes muito pequenos, os maiores são difíceis de serem domesticados). É uma cena corriqueira no final de caçadas como aquela. Porém, o que para as pessoas parecia não ser nada de especial - e muito desconcertante para mim - era o fato de aquele filhote morto, abraçado à sua mãe, ser um primata de outra espécie. Eu não estava diante de um filhote de macaco-prego (Sapajus apella) que morreu abraçado à sua mãe macaco-prego (Sapajus apella), mas de um filhote de cuxiú-preto (Chiropotes satanas), que fazia as vezes de "filhote" daquela fêmea. Não eram apenas espécies diferentes, mas gêneros e famílias diferentes. O macaco-prego

47 TSING, Anna, 20I5, op. cit., p. I84.

48 STRATHERN, Marilyn, I980, op. cit. 
pertence à família Cebidae (ou cebídeos) e gênero Sapajus. O cuxiú-preto é classificado como da família Pitheciidae e gênero Chiropotes. A minha primeira reação foi perguntar aos meus amigos o que estava acontecendo. Isso existia? Era possível? Quando alguém me respondeu que era perfeitamente possível, e que aquela fêmea tinha pegado aquele cuxiú para criar, assim como os humanos criam filhos humanos e filhotes de animais nas aldeias. Foi aí que percebi que eu deveria levar não apenas os Guajá a sério, mas também os macacos e, enfim, os animais.

Também nunca fui desses que procuram na biologia a explicação para as falas "nativas". Mas esse tipo de "interação interespecífica" cooperativa é um tema na primatologia e ocorre com diferentes espécies de primatas de áreas tropicais que dividem o mesmo habitat durante o mesmo tempo ${ }^{49}$. Apesar de a maior parte das interações ser de competição, envolvendo agressividade entre as espécies, nem sempre isso se verifica ${ }^{50}$. O tema abrange equações e princípios de biologia, com possibilidades e impossibilidades etológicas, nichos específicos e outros elementos que foge aos propósitos deste artigo observar ${ }^{51}$. Porém, as diferentes formas de interação entre primatas podem ter se acentuado com o impacto e pressões ambientais em diversas áreas onde o fenômeno é encontrado. Em outras palavras, o desmatamento pode fazer os animais se matarem mais, ou se unirem mais. O que faz da explicação guajá de que a fêmea de macaco-prego pegou o filhote de cuxiú para cuidar um argumento poderoso e de grande complexidade. Nesse caso, a relação escapava aos humanos, e o meu interesse não poderia se deter apenas a um estudo entre humanos e não humanos. Os macacos tinham os seus próprios problemas interespecíficos, que por sua vez eram importantes para mim.

Tal episódio remonta ao problema da relação que descrevi em minha etnografia (com os humanos), e pode ser definido a partir da ideia de que alguns seres são pensados como aparecendo junto a outros, literalmente ${ }^{52}$. São seres que, de acordo com a etologia guajá "andam juntos" (watá pyry), com algumas espécies de seres criando outras, tal como, em alguns aspectos, também é de interesse da biologia. Por exemplo,

49 BOURLIÈRE, François. Primate communities: their structure and role in tropical ecosystems. International Journal of Primatology, n. 6, I985, p. I-26. http://dx.doi.org/I0.I007/bf02693694; CRISTÓBAL-AZKARATE, Jurgi; URBANI, Bernardo; ASENSIO, Norberto. Interactions of Howler monkeys with other vertebrates: a review. In: KOWALEWSKI, Martin et. al. (Ed.). Howler monkeys - Developments in primatology: progress and prospects, 20I5. http://dx.doi.org/I0.I007/978-I-4939-I960-4_6; ROSE, Lisa et al. Interspecific interactions between Cebus capucinus and other species: data from three Costa Rican sites. International Journal of Primatology, v. $24, \mathrm{n}$. 4, 2003, p. 759-796.

50 BUCHANAN-SMITH, Hanna et al. Interspecific interactions and welfare implications in mixed species communities of capuchin (Sapajus apella) and squirrel monkeys (Saimiri sciureus) over 3 years. Applied Animal Behaviour Science I47, p. 324-333, 2013. http://dx.doi.org/Io.IoI6/j.applanim.2013.04.004; CRISTÓBAL-AZKARATE, Jurgi; URBANI, Bernardo; ASENSIO, Norberto, op. cit.; ROSE, Lisa et al., op. cit.

5I BUCHANAN-SMITH, Hanna et al., op. cit.; ROSE, Lisa et al., op. cit.; SENF, Melissa Joy. Interspecic and integroup interactions of mantled howling monkeys (Alouatta palliata) in primary versus secondary forest at El Zota Biological Field Station, Costa Rica. Master Thesis. Iowa State University, 2009.

52 GARCIA, Uirá. Sobre o poder da criação: parentesco e outras relações awá-guajá. Mana, v. 2I, n. I, 20I5, p. 9I-I22. 
na América do Sul, macacos do gênero Cebus/Sapajus (como o macaco-prego) podem ter relações de "cuidado" com o mico-de-cheiro (Saimiri sciureus)53, bem como os bugios (gênero Alouatta) e os macacos-pregos (Cebus/Sapajus) são espécies de constantes trocas interespecíficas ${ }^{54}$. No pensamento guajá, esse processo de “andar junto" é uma maneira que as pessoas têm para pensar os animais e suas classificações onde diversos animais possuem relações de criação para com outros animais e, literalmente, alguns seres serão criados por outros. Tomemos algumas espécies como exemplo:

- formigas tucandeiras são animais de criação dos capelães;

- o macaco cuxiú-preto cria um tipo de tucano chamado kakỹ (por exemplo, esses tucanos, quando cantam, o fazem para chamar esses animais que "estão junto" deles, os macacos cuxiú-preto);

- o veado mateiro tem as cotias e algumas espécies de borboleta como seus animais de criação;

- as cotias e os quatis criam esquilos quatipuru;

- os queixadas criam as cobras surucucu;

- o pássaro surucuá-de-barriga-vermelha (Trogon curucui) é chamados tatu nima, ou seja, "animal de criação dos tatus";

- os pássaros chora-chuva-preto (Monasa nigrifons) são pensados como "animais de criação do capelão";

- as espécies de cigarras conhecidas como jakaramuhũm são pensadas como "animais de criação das palmeiras babaçu”;

- os sabiás são animais de criação das capivaras.

Haveria outros exemplos, mas, de maneira geral, muitos animais caçados pelos humanos são animais de criação de outros animais. Para além da humanidade, a vida nas florestas do Maranhão se desenrola sob diversas formas, onde animais e plantas se interconectam, em uma rede de vidas tal uma "ecologia de sujeitos" (ecology of selves), para evocar a forma de Eduardo Kohn"5. São formas de propagação do animal que passam pela aliança (ou mesmo contágio) entre espécies ${ }^{56}$. Tais multiplicidades, portanto, escapam à nossa forma habitual de entender, por exemplo, as relações entre espécies.

Não quero sugerir, no entanto, que encontraremos cenas de animais de espécies, ordens e famílias diferentes convivendo em cooperação, como de fato encontrei aquela fêmea e o filhote de macaco. Mas isso abre um campo de possibilidades para refletir aqui não só de que forma as pessoas classificam a fauna, mas como pensam de maneira mais ampla sobre como os animais se pensam, se comportam, estão no mundo, enfim, um outro conceito de animal em que "as diferenças interespecíficas

53 SENF, Melissa, op.cit.

54 CRISTÓBAL-AZKARATE, Jurgi; URBANI, Bernardo; ASENSIO, Norberto, op. cit.

55 KOHN, Eduardo, 20I3, op. cit.

56 DELEUZE, Gilles; GUATTARI, Félix. Mil platôs: capitalismo e esquizofrenia. V. 4. Trad. Suely Rolnik. São

Paulo: Ed. 34, I997. 
são blocos de virtualidades relacionais, de modos de posicionamento relativo das espécies entre si"57. O que os Guajá parecem sugerir é a existência de algo como um "acordo simbiótico", na formulação de Isabelle Stengers ${ }^{58}$, uma aliança entre espécies, para além dos humanos. E tudo o que os humanos podem fazer é especular sobre tais relações. De acordo com essa forma de pensar e agir, as espécies mesmas parecem se pensar como algumas sendo favoráveis a andar juntas de outras, produzindo uma "vizinhança”"59 entre seres que, para nós, nem sempre andarão juntos. Um tipo de "companheirismo interespecífico intrigante" 60 . Trata-se de outras formas de se conceber aquilo que nós, etnólogos sul-americanistas, chamamos de aliança, no sentido estrito. Recorto aqui, a ideia de relações (ou alianças) entre espécies, "no vasto domínio das simbioses, que envolve seres de escalas e reinos totalmente diferentes" ${ }^{\text {"6I, }}$ produzindo ali "alianças contra-natureza entre as espécies"62. Esse "andar junto" (wata pyry), portanto, traduz parte da vida nas aldeias guajá, que, como em tantas aldeias na América do Sul, são locais de convívio entre os humanos e os mais diferentes animais, implicando tais naturezasculturas em outros problemas. Por isso que, em minha etnografia, a caça no geral e a caça de macacos em particular, estou me obrigando a pensar sobre noções importantes para nós tais como animal e espécie.

A caça indígena sul-americana conecta pessoas e animais através de relações que passarão ora pela criação (de filhotes), ora pelo abate de adultos da espécie, mas que nunca serão concomitantes, tal como ocorre conosco em casos como, por exemplo, a criação de bois e galinhas. Podemos dizer que "nós" criamos, matamos e comemos bois e galinhas. Tomando a vida guajá como exemplo, em outras palavras, o que se cria não se mata, o que se mata não foi criado, e isso pode não ser trivial. Davi Kopenawa, por exemplo, horrorizado com os hábitos alimentares dos brancos deixa bem claro: "Não queremos comer animais de criação. Achamos nojento e nos dá tonturas!" $"$.

O selvagem ( $k a^{\prime} a$ ) e o doméstico (tipa) não parecem encontrar ecos automáticos em outras oposições (supostamente) derivadas, como o já mencionado "par" masculino e feminino ou, então, humanidade e animalidade. A "animalidade" de um animal de criação, muito provavelmente, em nada se conecta à animalidade de um animal selvagem que será caçado. Diferentes modos de relação recortam os animais em duas categorias distintas entre si: hanima ("meu animal de criação") e ma'amiara ou apenas ma’a ("presa”, "caça", "bicho"). Um animal que é tratado por presa nunca será de

57 VIVEIROS DE CASTRO, Eduardo. The notion of species in history and anthropology. Translated by Frederico Santos Soares de Freitas and Zeb Tortorici. Biozoo, v. Io, n. I, 2013, p. 4. Disponível em: <https://goo. gl/MmDzLa . Acesso em: I5 set. 20I7.

58 STENGERS, Isabelle. Cosmopolitics I. Minneapolis: University of Minnesota Press, 20Io, p. 35.

59 DELEUZE, Gilles; GUATTARI, Félix, op. cit., p. 64.

6o TSING, Anna, 20I5, op. cit., p. I82.

6I DELEUZE, Gilles; GUATTARI, Félix, op. cit., p. I9.

62 VIVEIROS DE CASTRO, Eduardo. Filiação intensiva e aliança demoníaca. Novos Estudos Cebrap, n. 77, 2007,

p. II8. http://dx.doi.org/I0.I590/soIoI-33002007000I00006.

63 KOPENAWA, Davi; ALBERT, Bruce, op. cit., p. 478-479. 
criação, e os filhotes capturados dessas presas (apenas os muito pequenos) raramente são vistos como "caças" (ma'amiara). A tônica, portanto, não recairá na espécie (tal como nós concebemos cachorros como um tipo de animal e jaguatiricas como outro), mas em distintas formas de relação, diferentes afecções. Como se os animais de um tipo (caçados) tivessem pouca relação com animais do outro tipo (criados), mesmo sendo - aos nossos olhos - da mesma espécie. A natureza das interações entre humanos e animais, na caça e na criação, é não apenas de universos diferentes, mas a própria ideia de animal pode não ser informada pela "animalidade" de certas espécies em oposição à “domesticidade” de outras, mas pela forma que os Guajá se relacionam com esses bichos. Por exemplo, tal como outros povos amazônicos, os Guajá não possuem uma palavra para animal, de um ponto de vista genérico ${ }^{64}$, mas possuem uma para animal caçável (ma'amiara), e outra para animal criável (hajma). Nessa lógica, um macaco-prego na floresta pode vir a ser mais perigoso do que uma onça doméstica (e as pessoas lembram todo o tempo o quanto os macacos-pregos são agressivos e “doidos"), não havendo um pressuposto de agressividade da espécie, embora os Guajá defendam que, no mato, uma onça (quase) sempre será mais perigosa que um macaco.

Certa feita, um amigo abatera um macaco-prego com um tiro na parte traseira do crânio. O cérebro do animal estava exposto, e mesmo depois de horas após a caçada podíamos ouvir no pátio de nosso acampamento o bicho moribundo lutando para não morrer. Lembro que aquela cena me atormentou, e acabei pedindo que alguém terminasse de vez com o animal para aliviá-lo (ou me aliviar) de tanto sofrimento. Foi quando todos que me ouviram desataram a rir, não sem acatar os meus apelos. Sobre o animal, além de mencionarem uma ideia que alguns Guajá defendem, que nunca entendi direito, a de que "bicho não sente dor" (nikaj hahyha), o outro comentário que fizeram, com muitas risadas, era o fato de aquele macaco resistente ser parecido com os "brancos" e ser difícil de matar ("de morrer", para ser mais preciso). É preciso dizer que pensar macacos como animais de caça, como comida, é estranha a nós, por exemplo, pois somos informados pela nossa primatologia, pelo nosso etnoconhecimento, da continuidade lógica e inseparável entre nós e os primatas não humanos, algo que os Guajá não compartilham. Basta pegarmos os estudos que comprovam a homologia genética entre humanos e primatas não humanos, alguns muito próximos como os bonobos $(98,7 \%)$. Meus amigos neutralizam essa continuidade ontológica muito facilmente retirando, não só os macacos, mas todos os animais caçáveis dessa linha de continuidade interespecífica de unidade na natureza - do tipo "somos todos animais" -, o que faz tudo mudar (algo que diversos autores também vêm criticando ${ }^{65}$ ). É como se, para os Guajá, a caça como um modo de interação em nada tivesse a ver com a criação de animais como um outro modo.

Sabemos que essas duas características são indissociáveis na caça amazônica, mas, no caso guajá, uma se vincula diretamente à outra, sendo a comida e a criação condicionantes entre si. Isso operaria algo como um duplo vínculo, tal a célebre

64 Por exemplo: VANDER VELDEN, Felipe, 2012, op. cit., p. 238.

65 LIMA, Tânia Stolze. O dois e seu múltiplo: reflexões sobre o perspectivismo em uma cosmologia tupi. Mana, v. 2, n. 2, I996, p. 2I-47. http://dx.doi.org/I0.I590/sOI0I-33002007000I00006. 
formulação de Gregory Bateson, na qual o que quer que se faça para se desvencilhar não há como vencer ${ }^{66}$ : para as pessoas criarem, precisam matar (pois se criam filhotes); para caçarem, precisam cuidar (pois sempre ficam os filhotes). É comum vermos homens que saem para o mato, para caçar, dizendo às suas filhas que trarão como lembrança um filhote de macaco ou de cotia, produtos da caçada que farão. Também vemos meninas que desatam a chorar por não terem um animalzinho de criação serem consoladas por seus pais e mães, que prometem trazer quando houver uma nova caçada. Os adultos reclamam que suas crianças choram querendo filhotes de macaco e cotia para criarem. Sendo assim - e como sabemos de tantos povos amazônicos -, na mesma jornada em que se produz comida na forma de caça, são capturados os animaizinhos para criação. Porém, ao invés de concluir aqui, como outros autores fizeram, que a criação desses animais funcionaria como uma compensação à morte dos mesmos, ou tese da má consciência do caçador, teses devidamente criticadas por Philippe Descola ${ }^{67}$, no que se refere a diferentes animais - comidos e criados -, esse fenômeno parece tensionar a própria ideia de espécie como algo dado ${ }^{68}$. Interessando-me, portanto, "em modalidades muito diversas que a relação entre caçadores e presas pode assumir na Amazônia"69, sugiro que, ao menos na perspectiva dos caçadores, parece que estamos diante de diferentes tipos de animais, por assim dizer, que aparecem como efeitos de relações (repito, ao menos para os humanos). Não apenas o próprio bicho, mas o tipo de relação importaria tanto quanto a espécie do animal. É a relação, se assim posso colocar, que parece primária aqui, seja no tratamento cuidadoso dos animais criados, seja na forma "impiedosa" que reservam aos animais caçados. Nesse caso, a própria noção de espécie (que, como sabemos, está em debate há pelo menos 150 anos na biologia ${ }^{70}$ ) seria subordinada por esse duplo vínculo, não havendo a espécie em si, mas "agenciamentos" de caça e outros de criação.

Se, por um lado, concordo com Ingold quando ele sugere que a noção de espécie é uma imposição antropocêntrica, e a noção de que criaturas podem ser agrupadas com base na similaridade e divididas com base na diferença deva ser repensada ${ }^{71}$, também sei que tal ideia, ao menos aqui de maneira crítica, "não pretende sugerir

66 BATESON, Gregory. (1956). Steps to an ecology of mind. Chicago and London: The University of Chicago Press, I972, p. 20I.

67 DESCOLA, Philippe. Estrutura ou sentimento: a relação com o animal na Amazônia: Mana, v. 4, n. I, I998, p. 23-45. http://dx.doi.org/I0.I590/s0I04-93131998000100002.

68 Por outro lado, fundamentar a crítica apenas no animismo pós-estruturalista (DESCOLA, Gregory, op. cit.), que se basearia em um antropocentrismo indígena, informado pela mitologia e xamanismo, se é filosoficamente sofisticado, resolveria apenas parte do problema pois, como lembra Viveiros de Castro, recorre-se à "projeção metafórica" a fim de dar conta de modos de personificação e relação muito distantes, ou mesmo opostos aos nossos. VIVEIROS DE CASTRO, Eduardo, 2007, op. cit., p. I08.

69 DESCOLA, Philippe, I998, op. cit., p. 35.

70 HARAWAY, Donna. The companion species manifesto. Dogs, people, and significant otherness. Chicago: Prickly Paradigm Press, 2003, p. I5.

7I INGOLD, Tim, 20I3, op. cit., p. I9. 
que os tipos são fixos ou homogêneos"72. Por isso a própria ideia de espécie, ela mesma, pode ser repensada etnograficamente, sem necessariamente termos que negá-la ou excluí-la. Apenas usá-la como mais uma "ficção" em nossas análises ${ }^{73}$ passível de problematização por diversos povos ameríndios. Em uma das etnografias mais interessantes na antropologia brasileira recente, João Paulo Barreto, de maneira brilhante (e algo satírica), esquadrinha a maneira canônica como biólogos manejam a noção de espécie, tomando-a (nessa fabricação do fato científic0 ${ }^{74}$ ) como a produção da própria verdade da natureza. Como vemos, os Guajá não têm qualquer compromisso com a nossa noção de espécie animal; por outro lado eles se relacionam intensamente com macacos, e reflexivamente macacos são animais que só sei pensar enquanto espécies - e não seriam quaisquer espécies, é da ordem dos primatas, a ordem à qual eu mesmo pertenço. Por isso, etnograficamente, são esses diferentes modos de relação que me interessam, e não os bichos, espécies, gêneros, ordens ou classes em si.

\section{MACACOS TAMBÉM CHORAM}

A ideia de Antropoceno sugere que só agora encontramos uma tradução algo próximo às experiências de vida conhecidas há séculos por tantos povos. É como se o horror pudesse agora ser vislumbrado, enfim, por parte dos centros de poder euro-americano, bem como as suas derivações coloniais e colonizadas. Trata-se de um evento-limite que marca descontinuidades graves, "o que vem depois não será como o que veio antes"75. Os nomes, como sabemos, são diversos: Antropoceno, Capitaloceno, Plantationoceno, Chthuluceno, Cena-de-supremacia-branca ${ }^{76}$, o que não significa que sejam sinônimos mutuamente reduzíveis, ao contrário, a multiplicidade de conceitos só problematiza, ainda mais, a "barbárie que se aproxima"77. O Brasil experimenta hoje o maior surto de febre amarela silvestre de que se têm notícias. Um "surto aterrorizante", de acordo com especialistas da Fundação Oswaldo Cruz, com uma interface rural e urbana ${ }^{78}$ inédita para essa doença. A Fiocruz conseguiu

72 HARAWAY, Donna, op. cit., 2003, p. I5-I6.

73 STRATHERN, Marilyn. (I988). O gênero da dádiva - problemas com as mulheres e problemas com a sociedade na Melanésia. Campinas: Editora da Unicamp, 2006.

74 LATOUR, Bruno. Ciência em ação: como seguir cientistas e engenheiros sociedade afora. São Paulo: Editora da Unesp, $20 I I$.

75 HARAWAY, Donna. Antropoceno, Capitaloceno, Plantationoceno, Chthuluceno: fazendo parentes. ClimaCom, ano 3, n. 5, 20I6, p. I39-I48. p. I40. Disponível em: 〈https://goo.gl/kIArGV〉. Acesso em: I5 set. 2017.

76 VAN DOOREN, Thom; KIRKSEY, Eben; MÜNSTER, Ursula, op. cit.

77 STENGERS, Isabelle. No tempo das catástrofes. Tradução de Eloisa Araújo Ribeiro. São Paulo: Cosac Naify, 2015.

78 "Desta vez, a infecção está partindo de pequenos fragmentos de matas e chegando a pequenas cidades da zona rural, onde a densidade populacional é maior, e se espalhando por uma ampla região geográfica que já abrange pelo menos três Estados, diz Barcellos. Ou seja, é a doença que está indo até as pessoas.” BARCELLOS, Christovam apud FÁBIO, André Cabette. Qual é a relação entre degradação ambiental e o surto de febre amarela. 29 jan. 20I7. Nexo - Expresso. Disponível em: 〈https://goo.gl/P9mZ4U〉. Acesso em: I5 set. 2017. 
realizar o sequenciamento do genoma de amostras do vírus retiradas de macacos oriundos do Espírito Santo, mortos em final de fevereiro de 20I7, e verificou "a presença de variações em sequências genéticas que estão associadas a proteínas envolvidas na replicação viral". Trata-se de mutações inéditas e sem registros anteriores na literatura científica mundial79. Há indícios de que o rompimento da barragem da Samarco em Mariana em 20I5 $5^{80}$ - o maior desastre ambiental de toda a história mundial envolvendo barragens de rejeitos - tenha desencadeado o surto de febre amarela que experimentamos em 20I7. A relação entre a barragem e o surto ainda está sendo aprofundada, mas é evidente que, com "a desestruturação química e infertilidade do solo, a destruição da vegetação local, o assoreamento dos rios, soterramento de nascentes e mudança na biota"8I, os macacos em particular sentiram violentamente os impactos no ambiente, sobretudo pela falta de alimentos e destruição do ecossistema. O rompimento da barragem pode ter provocado um quadro de grande sofrimento dos primatas tornando-os mais suscetíveis a doenças como a febre amarela ${ }^{82}$.

Em uma época em que o "deserto" - enquanto espaços onde vidas e extinção tensionadas são única forma de viver - e o "vírus" - uma boa imagem para pensar o interstício entre seres vivos e não vivos, em que uma das conotações seria um tipo de vida que produz morte ${ }^{83}$ - são caminhos para pensar sobre um tipo de poder que é a própria manutenção da diferença entre "vida" (seres) e "não vida" (geos), aquilo que Elizabeth Povinelli chama de "poder geontológico" (geontoligical power), surtos como esse ${ }^{84}$, apesar de serem computados ao "capitalismo mundial integrado" 85 , têm como resultado inicial uma agressão a "viventes que nada têm a ver com a questão"

79 IOC/Fiocruz. Instituto Oswaldo Cruz. Pesquisadores identificam mutações na sequência genética do vírus da febre amarela. I7/5/20I7. Disponível em: 〈https://goo.gl/p7NZh7〉. Acesso em: I5 set. 20I7.

80 ROMPIMENTO de barragem em Mariana. Wikipédia. Disponível em: $\langle$ https://goo.gl/VyNsMc $\rangle$. Acesso em: I5 set. 2017 .

8I GARCIA, Isabela Balau. A sustentabilidade e o desastre em Mariana. Envolverde - jornalismo e sustentabilidade. 22/I/20I6. Disponível em: <envolverde.cartacapital.com.br/a-sustentabilidade-e-odesastre-em-mariana $>$. Acesso em: I5 set. 20I7.

82 FORMENTI, Lígia. Para bióloga, surto de febre amarela pode ter relação com tragédia de Mariana. O Estado de S. Paulo, I4 janeiro 20I7. Disponível em: <saude.estadao.com.br/noticias/geral,para-biologa-surto-de-febreamarela-pode-ter-relacao-com-tragedia-de-mariana,I0000I00032>. Acesso em: I5 set. 2017.

83 POVINELLI, Elizabeth. Geontologies: a requiem to late liberalism. Durham and London: Duke University Press, 2016.

84 Nesse momento (outubro de 20I7), após um ano tentando ser controlado na Região Sudeste, o surto chegou ao município de São Paulo, já levando à morte alguns macacos no Parque Anhanguera (zona norte da cidade). DIÓGENES, Juliana; MENGUE, Priscila. Mais dois macacos têm teste positivo para febre amarela na capital paulista. 28/Io/20I7. UOL Notícias Ciência e Saúde. Disponível em: <https://noticias.uol.com.br/ saude/ultimas-noticias/estado/20I7/Io/28/mais-dois-macacos-tem-teste-positivo-para-febre-amarela-nacapital-paulista.htm>. Acesso em: out. 2017 .

85 DANOWSKI, Déborah; VIVEIROS DE CASTRO, Eduardo, op. cit.

86 STENGERS, Isabelle, 20I5, op. cit., p. 40. 
Não apenas os humanos financeiramente mais pobres, mas uma vasta população de refugiados não humanos sem refúgios ${ }^{87}$, como os macacos.

Até Io de agosto de 20I7, "o número de casos confirmados do surto chegou a 777 em 407 cidades brasileiras, com 266 mortes confirmadas" 88 . Não sabemos ao certo o número de macacos mortos, porém estimativas genéricas do Ministério da Saúde apontam para cerca de 5.500 macacos na Região Sudeste ${ }^{89}$. Humanos e macacos, concomitantemente, estão morrendo de febre amarela, mas, de acordo com a Sociedade Brasileira de Primatologia, ambos são vítimas, e "os macacos não são reservatórios da doença" ${ }^{\circ}$. Apesar disso, humanos estão exterminando os macacos como se os animais fossem os responsáveis por hospedar ou transmitir o vírus. $\mathrm{O}$ que estamos vendo em diversas regiões é um extermínio ilegal de macacos infectados e não infectados, tratados como reservatório da doença, e isso é mais problemático quando sabemos que $70 \%$ dos primatas não humanos da Mata Atlântica estão ameaçados de extinção ${ }^{91}$. Se a ecologia (e seus muitos desdobramentos) tem esse "duplo significado", científico e político92 , é como se (neste caso) a ciência não tivesse qualquer relação com a política e, não importa o que digam os primatólogos, os macacos continuarão sendo exterminados.

Dentre todas as espécies de primatas não humanos, a mais atingida pela febre amarela, além dos micos (Callithrix), são diversos animais do gênero Alouatta, os capelães93, conhecidos no Sudeste brasileiro como "bugios", de que tanto gostam os Guajá. São eles os mais sensíveis ao vírus, e são eles, como dizem os Guajá, animais "sensíveis" de um modo geral, como expus anteriormente. Evocando novamente o "canto" do capelão, diversas pessoas, desde agricultores do Espírito Santo a donos de reservas particulares particulares do patrimônio nacional (RPPNs) em Minas Gerais, estão dizendo que a mata está silenciosa. Em algumas dessas reservas, nos últimos meses, a população de bugios se extinguiu em $80 \% 94$. O que é mais catastrófico é que, por estarem sendo tratados como "vetores" da doença (e não vítimas), os bugios estão morrendo duas vezes com esse surto: pelo vírus em si e pela estupidez humana, o que tem feito autoridades de saúde no Brasil alertarem a população a não matarem os

87 HARAWAY, Donna, 20I6, op. cit, p. Ioo

88 SURTO de febre amarela no Brasil em 20I7. Wikipédia. Disponível em: 〈https://goo.gl/mBE6AE $\rangle$. Acesso em: I5 set. 20I7.

89 CARNEIRO, Júlia Dias. Febre amarela pode acelerar extinção de macacos ameaçados. 29 maio 20I7. BBC Brasil. Disponível em: 〈https://goo.gl/76ZTSq〉. Acesso em: I5 set. 2017.

90 SBPr - Sociedade Brasileira de Primatologia. O surto de febre amarela no Brasil e seus impactos sobre a população de macacos. 20I7. Nota de esclarecimento aos profissionais da imprensa, jornalistas e formadores de opinião. Disponível em: 〈https://goo.gl/Ks8AgJ〉. Acesso em: I5 set. 2017.

9 I CARNEIRO, Júlia Dias, op. cit.

92 STENGERS, Isabelle, 20Io, op. cit, p. 32.

$93 \mathrm{SBPr}$, op. cit.

94 CARNEIRO, Júlia Dias, op. cit. 
macacos ${ }^{95}$. Estes têm sido mortos a pauladas, pedradas, tiros, envenenamento... e já foram encontrados inclusive macacos queimados e com o crânio esmigalhado (como vêm anunciando diversos portais de notícias). Se os transmissores da febre amarela silvestre são algumas espécies de mosquito dos gêneros Haemagogus e Sabethes ${ }^{96}$, mesmo eles só transmitem, pois saem do controle em áreas desmatadas pelos humanos. Nessa lógica os humanos são mais a origem da doença do que qualquer animal. Os macacos são puramente vítimas. Ainda assim, nesse caso, a febre amarela está aparecendo como se fosse algo inerente à natureza dos macacos, como se só fosse possível, em momentos de crise, pensá-los em duas caixas: politicamente, como uma ameaça aos humanos, ou cientificamente, a partir dos esclarecimentos dos cientistas. Crises como essa revelam, em muito, como pensamos o ambiente. Ameaça ou controle.

Se os biólogos vêm afirmando que o surto de febre amarela é decorrência da degradação ambiental, e em nada tem a ver com os macacos, os próprios Guajá nos ensinam que existem outros agenciamentos que fazem dos bugios seres muito mais complexos do que aquele a que o surto de febre amarela os reduz. Em falas recentes, em reuniões que acompanhei para a organização de sua associação indígena, ao falarem de recuperação ambiental, os Guajá evocam a necessidade de recuperar a floresta para que os capelães (bugios) possam viver. Apesar de mencionarem outros animais, o exemplo são os macacos em geral, e o capelão especificamente. Podemos dizer que os Guajá (que estão em uma das regiões mais desmatadas da Amazônia continental) vêm reivindicando em suas falas a floresta para os animais.

Como contraposição, uma reportagem publicada no New York Times ${ }^{97}$ e traduzida no site UOL, na qual uma das maiores preocupações era se o vírus atravessaria ou não o canal do Panamá), uma passagem que chama atenção é: "Os que matam macacos estão agravando a situação, ao dizimar as populações de macacos que servem como indícios de onde a febre está se espalhando" 98 . De acordo com uma "autoridade do Ministério da Saúde"99, quem mata macacos está colocando os seres humanos em risco ainda maior ao matar o "mensageiro". Tudo aparece como se, para grande parte da imprensa, a morte de macacos estivesse reduzida a um "alerta" aos humanos. Nessa lógica, eles não passam disso, de ser o nosso escudo? Eles devem morrer para nós ficarmos vivos, apesar de nós termos desmatado, e eles (os macacos) não? Matar

95 ROMERO, Simon. Pesquisadores fazem apelo no surto de febre amarela: não matem os macacos. Colaboração de Ernesto Londoño, Cambridge, Paula Moura, São Paulo, Dom Phillips, Rio de Janeiro. Trad. Luiz Roberto Mendes Gonçalves. 4/5/20I7. UOL Notícias Ciência e Saúde. Disponível em: 〈https://goo.gl/SE8pvh〉. Acesso em: I5 set, 2017.

96 O Aedes aegypti é o transmissor da febre amarela urbana.

97 ROMERO, Simon. Brazil yellow fever outbreak spawns alert: stop killing the monkeys. Ernesto Londoño contributed reporting from Cambridge, Mass., Paula Moura from São Paulo, Brazil, and Dom Phillips from Rio de Janeiro. The New York Times. May 2 20I7. Disponível em: 〈https://goo.gl/Zv4LIJ〉. Acesso em: I5 set. $20 I 7$. 98 ROMERO, Simon. Pesquisadores fazem apelo..., op.cit.

99 Ibidem. 
"é a forma mais comum de interação humana com animais" para conter a gripe aviária, vacas para nos poupar da "vaca louca”, mas isso não é levado a sério ${ }^{\mathrm{IOI}}$. É como admitir que, na nossa lógica de sacrifício, todo ser vivo exceto o homem é um ser matável, "só os seres humanos são assassinados" "102. As ideias guajá acabam revelando muito de como agimos diante de problemas como esse. Para os meus amigos, a febre amarela não só não é da natureza dos bugios, como eles tampouco seriam simplesmente "espécies sentinelas", prontas para morrer em benefício da humanidade. Enfim, "não é matar que nos leva ao exterminismo, mas sim tornar os animais matáveis"ז03.

Esse caso explicita que não sabemos o que é multiplicidade, tampouco multiespecificidade ou qualquer outro acordo inclusivo entre nós e outros animais (e mesmo quaisquer seres não humanos). Evocando as palavras de Werner Herzog, em $O$ Homem Urso ${ }^{\mathrm{IO}} 4$, os fatos mostram que o denominador comum na natureza e no universo não é a harmonia, mas "o caos, a hostilidade e o assassinato". Pelo menos a reação a esse surto corrobora a ideia de Herzog. Se perdemos o controle sobre a natureza - e no caso desse surto nós perdemos completamente -, ela se transforma em nossa inimiga, e temos que ou exterminar os macacos, como vem fazendo parte da população, ou os macacos devem morrer para nos proteger, como "indícios de onde a febre está se espalhando”. A inclusão só funcionará enquanto dominarmos a natureza. Quando perdemos o controle sobre ela, a morte de animais (e morte de animais causa comoção a muitas poucas pessoas no mundo) não é problema algum. Uma última pergunta que surge seria: um problema dessa magnitude, que envolve humanos, animais, ciência e a própria sobrevivência das últimas espécies de macacos da floresta atlântica, e nossa única preocupação é que a doença está chegando aos humanos, e os macacos são um índice da doença? Isso é sério? É tudo o que a imprensa tem a dizer? É somente essa a nossa contribuição, conceitualmente?

Para finalizar, o documentário Virunga ${ }^{\text {To5, }}$, sobre o Parque Nacional de Virunga, na República Democrática do Congo, mostra uma das últimas populações no mundo de gorilas-das-montanhas. Virunga, assim como tantas terras indígenas brasileiras, possui o subsolo repleto de riquezas, dentre elas jazidas de petróleo. A indústria do petróleo na África é impulsionada não só pelo lucro, mas, como sabemos, pelo racismo (como se observa no filme, em diversas declarações). Em uma das cenas vemos um empregado da petroleira Soco - empresa que tem ações na bolsa de Londres - dizer que a única coisa que justificaria a proteção do parque e dos gorilas seria se eles (os gorilas) “cagassem diamantes e mijassem minério de ferro”. Para esse elemento, é inconcebível que I30 guardas florestais africanos tenham morrido

Ioo Animal Studies Group, 2006 apud HARAWAY, Donna, 20II, op. cit, p. 40.

IOI Ibidem.

I02 Ibidem, p. 39.

I03 Ibidem p. 43.

I04 O HOMEM urso. Direção de Werner Herzog. Produção de Erik Nelson. EUA, 2005. (I03 min.), son., color.

I05 Documentário britânico de 20I4. Direção de Orlando von Einsiedel. Congo, Grã-bretanha, Irlanda do Norte, 20I4. (Ioo min.), son., color. 
protegendo o parque e os gorilas apenas por se preocuparem com o parque e com os gorilas. Em outra passagem, um jovem francês, funcionário dessa mesma empresa petroleira, comenta sobre uma sucessão de mortes de gorilas que estava em curso (mortes essas - tudo leva a crer - financiadas pelo dinheiro do petróleo). E assim ele diz: "Que droga [what a fuck!], são só macacos. Quem se importa com a droga [fuck] de um macaco?".

Retirar a centralidade do humano de nossa teoria social é algo que-diferentemente de tantos povos indígenas sul-americanos e alhures - não conseguimos fazer, apesar de nossas tentativas e aproximações. Um ponto final a se destacar é que, na antropologia social, as "etnologias indígenas" nunca se contentaram em contar apenas histórias humanas. Mas isso não pode ser tudo. Sim, sabemos que nos mundos ameríndios "a diferença entre as espécies não é, para começar, anatômica ou fisiológica, mas comportamental ou etológica (o que distingue as espécies é muito mais seu etograma - o que comem, onde habitam, se vivem em grupo ou não. etc. - do que sua morfologia)" "ro6, tal como definem os Guajá - que pensam os bichos como "animais do chão" "do alto" "do buraco" "das folhas" etc. -, assim como diversos outros povos indígenas. Ao lado disso, o princípio de "alternação" que caracteriza o perspectivismo ameríndio, aquele de que "duas espécies (ao contrário de dois

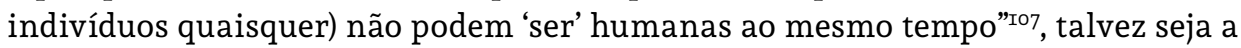
primeira pista para uma antropologia-para-além-do-humano. É um (novo) ponto de partida, digamos assim. Mas tal "alternação" encontra outra modalidade de ação - uma variação dessa proposição perspectivista - na ideia ameríndia (guajá, certamente) de que a priori dois animais não serão da "mesma espécie" apenas pela sua morfologia ou etologia. No sentido particular que este texto tenta demonstrar, etologia e morfologia não são um pressuposto em uma noção ameríndia de espécie, que escapa a um essencialismo característico dessa noção. O caráter relacional (ou relacionalista) é a tônica nos exemplos que trago aqui.

Os nossos conceitos de "animal”, "vegetal”, "primata”, “espécie”, dentre tantos outros, remetem quase sempre ao nosso universo social, é preciso sempre lembrar disso ${ }^{\text {To8 }}$, apesar dos efeitos práticos (ou "reais") na produção de toda a produção científica. Não se trata de finalizar esta reflexão produzindo uma crítica arrogante (ao mesmo tempo que simplista) à ciência a fim de "revelar" o que ela não enxergaria, ou outra simplificação desse tipo. A própria noção de espécie em que este texto se apoia é uma ficção generalista de uma ideia que, apesar de ainda atuar na biologia, experimenta sistemática e rápida transformação ${ }^{\mathrm{I0} 9}$. Ao contrário, sugiro assumirmos a vocação reflexiva da antropologia e operarmos em um duplo e sistemático

IO6 VIVEIROS DE CASTRO, Eduardo, 20I3, op.cit.

I07 Ibidem.

I08 Sabemos, por exemplo, que o idioma social do "parentesco" (daquele mesmo que buscamos nos "outros") baseia tanto a teoria da evolução quanto complexos cálculos de algoritmos genéticos. BEER, I983, e HELMREICH, I998 apud STRATHERN, Marilyn. Kinship, law and the unexpected. Relatives are always a surprise. Cambridge: Cambridge University Press, 2005, p. I8I-I82.

Io9 HARAWAY, Donna, 2008, op.cit. 
movimento analítico em que, por exemplo, pensar os animais a partir dos “outros" é desnudar também os animais que logo somos.

\section{SOBRE O AUTOR}

UIRÁ GARCIA é professor de Antropologia da Universidade Federal de São Paulo (Unifesp) e docente colaborador do Centro de Estudos Ameríndios (CEstA/ USP) e do Núcleo de Antropologia Simétrica (NAnSi) do PPGAS do Museu Nacional/UFRJ.

E-mail: ufgarcia@gmail.com

\section{REFERÊNCIAS BIBLIOGRÁFICAS}

ALOUATTA belzebul. Wikipédia. Disponível em: <goo.gl/hNPDmt>. Acesso em: I5 set. 2017.

BARRETO, João Paulo. Wai-Mahsã̃: peixes e humanos - um ensaio de antropologia indígena. Dissertação (Mestrado em Antropologia Social). Programa de Pós-Graduação em Antropologia Social, Universidade Federal do Amazona, 2013.

BATESON, Gregory. (1956). Steps to an ecology of mind. Chicago and London: The University of Chicago Press, I972, p. 207.

BOURLIÈRE, François. Primate communities: their structure and role in tropical ecosystems. International Journal of Primatology, n. 6, I985, p. I-26. http://dx.doi.org/I0.I007/bfo2693694.

BUCHANAN-SMITH, Hanna et al. Interspecific interactions and welfare implications in mixed species communities of capuchin (Sapajus apella) and squirrel monkeys (Saimiri sciureus) over 3 years. Applied Animal Behaviour Science 147, 2013, p. 324-333, 2013. http://dx.doi.org/Io.IoI6/j.applanim.2013.04.004. CARNEIRO, Júlia Dias. Febre amarela pode acelerar extinção de macacos ameaçados. 29 maio 20I7. BBC Brasil. Disponível em: 〈https://goo.gl/76ZTSq >. Acesso em: I5 set. 2017.

CORMIER, Loretta A. Monkey as food, monkey as child: Guajá symbolic cannibalism. In: FUENTES, AgustÎn; WOLFE, Linda D. (Org). Primates face to face: conservation implications of human-nonhuman primate interconnections. Cambridge: Cambridge University Press, 2002, p. 63-84.

. Kinship with monkeys: the Guajá foragers of eastern Amazonia. New York: Columbia University Press, 2003.

CRISTÓBAL-AZKARATE, Jurgi; URBANI, Bernardo; ASENSIO, Norberto. Interactions of Howler monkeys with other vertebrates: a review. In: KOWALEWSKI, Martin et. al. (Ed.). Howler monkeys - Developments in primatology: progress and prospects. 20I5. http://dx.doi.org/I0.I007/978-I-4939-I960-4_6.

DANOWSKI, Déborah; VIVEIROS DE CASTRO, Eduardo. Há mundo por vir? Ensaio sobre os medos e os fins. Florianópolis: Cultura e Barbárie, 20I4.

DELEUZE, Gilles; GUATTARI, Félix. Mil platôs: capitalismo e esquizofrenia. V. 4. Trad. Suely Rolnik. São Paulo: Ed. 34, I997. 
DESCOLA, Philippe. Estrutura ou sentimento: a relação com o animal na Amazônia: Mana, v. 4, n. I, I998, p. 23-45. http://dx.doi.org/Io.I590/s0I04-93I3I998000I00002.

DESPRET, Viniciane. The body we care for: figures of anthropo-zoo-genesis. Body and Society, v. Io, n. 2/3, 2004, p. III-I34. http://dx.doi.org/Io.II77/I357034x04042938.

DIÓGENES, Juliana; MENGUE, Priscila. Mais dois macacos têm teste positivo para febre amarela na capital paulista. 28/Io/20I7. UOL Notícias Ciência e Saúde. Disponível em: <https://noticias.uol.com. br/saude/ultimas-noticias/estado/20I7/Io/28/mais-dois-macacos-tem-teste-positivo-para-febre-amarela-na-capital-paulista.htm >. Acesso em: out. 2017.

EMMONS, Louise H. Neotropical rainforest mammals: a field guide. Chicago: University of Chicago Press, I999.

FÁBIO, André Cabette. Qual é a relação entre degradação ambiental e o surto de febre amarela. 29 jan. 20I7. Nexo - Expresso. Disponível em: 〈https://goo.gl/PgmZ4U〉. Acesso em: I5 set. 2017.

FORMENTI, Lígia. Para bióloga, surto de febre amarela pode ter relação com tragédia de Mariana. $O$ Estado de S. Paulo, I//I/20I7. Disponível em: <saude.estadao.com.br/noticias/geral,para-biologa-surtode-febre-amarela-pode-ter-relacao-com-tragedia-de-mariana,I0000I00032>. Acesso em: I5 set. 2017. FUENTES, Agustín. Naturalcultural encounters in Bali: monkeys, temples, tourists, and ethnoprimatology. Cultural anthropology, v. 25, n. 4, 2010, p. 600-624.

. Ethnoprimatology and the anthropology of the human-primate interface. Annual Review of Anthropology, n. 4I, 20I2, p. IOI-I7, 2012.

GARCIA, Isabela Balau. A sustentabilidade e o desastre em Mariana. Envolverde - jornalismo e sustentabilidade. 22/I/20I6. Disponível em: <envolverde.cartacapital.com.br/a-sustentabilidade-e-o-desastre-em-mariana . Acesso em: I5 set. 2017.

GARCIA, Uirá. Karawara: a caça e o mundo dos Awá-Guajá. Tese (Doutorado em Antropologia Social). Faculdade de Filosofia, Letras e Ciências Humanas, Universidade de São Paulo, 2010.

. Sobre o poder da criação: parentesco e outras relações awá-guajá. Mana, v. 2I, n. I, 20I5, p. 9I-I22.

HALLOWELL, Irving. Ojibwa ontology, behavior and world view. In: DIAMOND, Stanley. Culture in history: essays in honor of Paul Radin. New York: Columbia University Press, I960, p. I9-52.

HARAWAY, Donna. The companion species manifesto. Dogs, people, and significant otherness. Chicago: Prickly Paradigm Press, 2003.

. When species meet. Minneapolis: University of Minnesota Press, 2008.

. A partilha do sofrimento: relações instrumentais entre animais de laboratório e sua gente. Horizontes Antropológicos, v. I7, n. 35, 20II, p. 27-64. http://dx.doi.org/I0.I590/s0104-718320Iroo0I00002. . Antropoceno, Capitaloceno, Plantationoceno, Chthuluceno: fazendo parentes. ClimaCom, ano 3, n. 5, 20I6, p. I39-I48. Disponível em: 〈https://goo.gl/kIArGV〉. Acesso em: I5 de set. 2017.

INGOLD, T. On reindeer and men. Man (New Series), v. 9, n. 4, I974, p. 523-538. http://dx.doi. org/10.2307/280п22.

. Anthropology beyond humanity. Suomen Anthropologi, v. 38, n. 3, 2013, p. 5-23.

IOC/Fiocruz. Instituto Oswaldo Cruz. Pesquisadores identificam mutações na sequência genética do vírus da febre amarela. I7/5/20I7. Disponível em: 〈https://goo.gl/p7NZh7〉. Acesso em: I5 set. 20I7.

KIRKSEY, S. Eben; HELMREICH, Stefan. The emergence of multispecies ethnography. Cultural Anthropology, v. 25, n. 4, 20I0. http://dx.doi.org/I0.IIII/j.I548-I360.20I0.0I069.x.

KOHN, Eduardo. How forests think: toward an anthropology beyond the human. Berkeley: University of California Press, 2013.

. Como os cães sonham: naturezas amazônicas e as políticas do engajamento transespécies. Ponto Urbe I9, 20I6, p. I-35. http://dx.doi.org/I0.400o/pontourbe.3326. 
KOPENAWA, Davi; ALBERT, Bruce. A queda do céu: palavras de um xamã yanomami. São Paulo: Companhia das Letras, 2015.

LATOUR, Bruno. Jamais fomos modernos: ensaios de antropologia simétrica. São Paulo: Editora 34, I994. . Políticas da natureza. Bauru: Edusc, 2004.

. Ciência em ação: como seguir cientistas e engenheiros sociedade afora. São Paulo: Editora da Unesp, 20II.

LATOUR, Bruno; STRUM, Shirley. The Meanings of Social: from Baboons to Humans. Information sur les sciences sociales/Social Science Information, 26, 1987, p. 783-802.

LIMA, Tânia Stolze. O dois e seu múltiplo: reflexões sobre o perspectivismo em uma cosmologia tupi. Mana, v. 2, n. 2, I996, p. 2I-47. http://dx.doi.org/I0.I590/s0I04-93I3I996000200002.

LIZARRALDE, Manuel. Ethnoecology of monkeys among the Bari of Venezuela: perception, use and conservation. In: FUENTES, Agustín; WOLFE, Linda D. (Org). Primates face to face: conservation implications of human-nonhuman primate interconnections. Cambridge: Cambridge University Press, 2002, , p. 85-Ioo.

OGDEN, Laura A.; HALL, Billy; TANITA, Kimiko. Animals, plants, people, and things: a review of multispecies ethnography. Environment and society: advances in research, 4, n. I, 20I3, p. 5-24. http://dx.doi. org/I0.3167/ares.2013.040102.

O HOMEM urso. Direção de Werner Herzog. Produção de Erik Nelson. EUA, 2005. (I03 min.), son., color. POVINELLI, Elizabeth. Geontologies: a requiem to late liberalism. Durham and London: Duke University Press, 2016.

ROMERO, Simon. Brazil yellow fever outbreak spawns alert: stop killing the monkeys. Ernesto Londoño contributed reporting from Cambridge, Mass., Paula Moura from São Paulo, Brazil, and Dom Phillips from Rio de Janeiro. The New York Times. May 2 20I7. Disponível em: 〈https://goo.gl/Zv4LIJ〉. Acesso em: I5 set. 2017 .

. Pesquisadores fazem apelo no surto de febre amarela: não matem os macacos. Colaboração de Ernesto Londoño, Cambridge, Paula Moura, São Paulo, Dom Phillips, Rio de Janeiro. Trad. Luiz Roberto Mendes Gonçalves. 4/5/20I7. UOL Notícias Ciência e saúde. Disponível em: <https://goo.gl/ SE8pvh>. Acesso em: I5 set, 2017.

ROMPIMENTO de barragem em Mariana. Wikipédia. Disponível em: 〈https://goo.gl/VyNsMc $>$. Acesso em: I5 set. 2017 .

ROSE, Lisa et al. Interspecific interactions between Cebus capucinus and other species: data from three Costa Rican sites. International Journal of Primatology, v. 24, n. 4, 2003, p. 759-796.

SAHLINS, Marshall. What kinship is (part one). JRAI - Journal of the Royal Anthropological Institute, v. I7, n. I, 20II, p. 2-I9. http://dx.doi.org/Io.IIII/j.I467-9655.20I0.0I666.x.

. What kinship is (part two). JRAI - Journal of the Royal Anthropological Institute, v. I7, n. 2, 20II, p. 227-242, 20II. http://dx.doi.org/IO.III/j.I467-9655.20II.0I677.x.

SANTOS, Rosana de Jesus Diniz. Awa Papejapoha: um estudo sobre educação escolar entre os Awá Guajá/ MA. Monografia (Especialização em Desenvolvimento e Relações Sociais no Campo). Universidade de Brasília, 2015.

SBPr - Sociedade Brasileira de Primatologia. O surto de febre amarela no Brasil e seus impactos sobre a população de macacos. 20I7. Nota de esclarecimento aos profissionais da imprensa, jornalistas e formadores de opinião. Disponível em: 〈https://goo.gl/Ks8AgJ〉. Acesso em: I5 set. 2017.

SENF, Melissa Joy. Interspecic and integroup interactions of mantled howling monkeys (Alouatta palliata) in primary versus secondary forest at El Zota Biological Field Station, Costa Rica. Master Thesis. Iowa State University, 2009. 
SHEPARD, Glenn. Primates in Matsigenka subsistence and world view. In: FUENTES, Agustín; WOLFE, Linda D. (Org). Primates face to face: conservation implications of human-nonhuman primate interconnections. Cambridge: Cambridge University Press, 2002, p. I0I-I36.

STENGERS, Isabelle. Cosmopolitics I. Minneapolis: University of Minnesota Press, 2010. . No tempo das catástrofes. Tradução de Eloisa Araújo Ribeiro. São Paulo: Cosac Naify, 2015.

STRATHERN, Marilyn. No nature, no culture: the Hagen Case. In: MACCORMACK, Carol; STRATHERN, Marilyn (Org.). Nature, culture and gender. Cambridge: Cambridge University Press, I980, p. I74-222. . Kinship, law and the unexpected. Relatives Are Always a Surprise. Cambridge: Cambridge University Press, 2005, pp. I8I-I82.

. (I988). O gênero da dádiva - problemas com as mulheres e problemas com a sociedade na Melanésia. Campinas: Editora da Unicamp, 2006.

. (I988). O gênero da dádiva - problemas com as mulheres e problemas com a sociedade na Melanésia. Campinas: Editora da Unicamp, 2006.

SURTO de febre amarela no Brasil em 20I7. Wikipédia. Disponível em: 〈https://goo.gl/mBE6AE 〉. Acesso em: I5 set. 2017 .

TSING, Anna. Arts of inclusion, or, how to love a mushroom. Australian Humanities Review 50, 20II, p. 5-22. . Margens indomáveis: cogumelos como espécies companheiras. ILHA v. I7, n. I, 20I5, p. I77-20. http://dx.doi.org/I0.5007/2I75-8034.20I5vI7nIpI77.

VAN DOOREN, Thom; KIRKSEY, Eben; MÜNSTER, Ursula. Estudos multiespécies: cultivando artes de atentividade. ClimaCom, ano 3, n. 6, Dossiê Incertezas, 20I6, p. 39-65. Disponível em: 〈goo.gl/uU27dR〉. Acesso em: I5 set. 2017.

VANDER VELDEN, Felipe Ferreira. Inquietas companhias: sobre os animais de criação entre os Karitiana. São Paulo: Alameda, 2012.

VIRUNGA. Direção de Orlando von Einsiedel. Congo, Grã-bretanha, Irlanda do Norte, 20I4. (I00 min.), son., color.

VIVEIROS DE CASTRO, Eduardo. O nativo relativo. Mana, v. 8, n. I, 2002, p. II3-I48. http://dx.doi. org/I0.I590/s0I04-93I32002000I00005.

. Filiação intensiva e aliança demoníaca. Novos estudos Cebrap, n. 77, 2007, p. 9I-I26. http://dx.doi. org/IO.I590/sOIOI-33002007000I00006.

. The notion of species in history and anthropology. Translated by Frederico Santos Soares de Freitas and Zeb Tortorici. Biozoo, v. Io, n. I, 20I3, p. 4. Disponível em: 〈https://goo.gl/MmDzLa〉. Acesso em: I5 set. 20I7. 